\title{
Impacts of Industrial Park Development on the Surroundings' Livelihood
}

\author{
Thanh Thuy CU ${ }^{1}$, Thi Hoai Huong HOANG ${ }^{2}$, Thi Yen LE $^{3}$ \\ Received: June 28, 2020 Revised: July 19, 2020 Accepted: August 10, 2020
}

\begin{abstract}
This study was conducted to analyze the impact of industrial park development on the livelihood of people living around the industrial parks in the Central region of Vietnam. The data was collected from 394 households living around these industrial parks; using the data, the authors employed a quantification model among factors affecting the income of families living in the surroundings of industrial parks and they calculate the adaptive capacity of households to consider the impact of the development of industrial parks on people's livelihood. Research findings show that industrial park development has both positive and negative impacts on the livelihood of people living around the industrial parks. Specifically, the factors that positively affect the income of households living around industrial parks include the area of land acquired due to the construction of industrial parks, the transportation system after the industrial park has located there, and the number of jobs available when the industrial park is being built. The factor that negatively affects the income of households living around industrial parks when they are under construction is the number of unemployed laborers. The study also calculated that the adaptive capacity of the people after the industrial park development is a coefficient of 0.376 .
\end{abstract}

Keywords: Livelihood, Households, Industrial Park Development, Central Region, Vietnam

JEL Classification Code: O10, O12, D14, D10, J22

\section{Introduction}

The development of industrial parks has been and is becoming an inevitable trend, not only in localities, but also across the nations; industrial parks are built and developed to become effective channels to mobilize investment capital by attracting enterprises to operate in industrial parks. Attracting enterprises operating in industrial parks creates relatively clear benefits for specific localities and countries: firstly, when enterprises operate in industrial parks, these enterprises will attract a large local as well as regional labor force, create jobs and solve social problems at the local as well as national levels. Besides, when industrial parks are

\footnotetext{
${ }^{1}$ First Author. Lecturer, Hanoi Architectural University, Viet Nam. Email: thanhthuyktdt85@gmail.com 2Lecturer, Quy Nhon University, Viet Nam. Email: hoangthihoaihuong@qnu.edu.vn

${ }^{3}$ Corresponding Author. Lecturer, Hanoi Architectural University, Viet Nam [Postal Address: Nguyen Trai Street, Ha Dong district, Ha Noi, 10000, Viet Nam] Email: Lethiyenktdt@gmail.com

(c) Copyright: The Author(s)

This is an Open Access article distributed under the terms of the Creative Commons Attribution Non-Commercial License (https://creativecommons.org/licenses/by-nc/4.0/) which permits unrestricted non-commercial use, distribution, and reproduction in any medium, provided the original work is properly cited.
}

built and developed, they create additional industries for people living nearby them. Secondly, enterprises operating in industrial parks, if they do so effectively, will contribute to the state budget, and the Government shall use the state budget to invest in health activities, education, infrastructure of localities, areas with industrial parks in particular and other regions of the country in general. Thirdly, industrial parks are built and developed in the regions; these areas will have to recover large agricultural lands as well as residential land of the people. When recovering the land, people will be financially compensated, so this money can create a nudge to change the livelihood strategies of people.

However, besides these positive aspects, the livelihood of people in the area where industrial parks are built and developed will also be negatively affected: firstly, households whose land is acquired will receive compensation, but if this compensation is not used appropriately, a new livelihood strategy is not developed. After a certain period, when this compensation is exhausted, households will have difficulty without materials and machinery to continue production. The income of households will then decline, and unemployment will rise. Second, enterprises operating in industrial parks will create new jobs for local workers; however, to be able to work at the enterprises will requires workers to possess certain professional skills. Therefore, a part of the local 
labor force does not meet the requirements leading to unemployment.

This study was conducted to analyze the impact of industrial park development on the livelihood of people living around these industrial parks. The study will examine the positive and negative impacts of industrial park development on the livelihood of people living around them. As regards data collection, the Central region was chosen as it is located in the heart Vietnam; this is a strategic region of economic exchange and is the gateway to the sea for the East-West corridor connecting to the international maritime route via the East Sea and the Pacific. The key economic region of Central Vietnam includes five provinces and cities: Thua Thien Hue, Da Nang, Quang Nam, Quang Ngai and Binh Dinh. This is also an area that is constantly developing and attracting a large amount of domestic and international investment in industrial parks.

By the end of 2018, the Central key economic region had 19 industrial parks, which were approved by the Prime Minister and are currently operating. These industrial parks occupy a natural land area of 4347.9 ha. The number of projects attracted to these industrial parks totals 913, of which the number of domestic investment projects is 716 and the foreign investment projects 197 projects. Enterprises operating in this industrial park have paid about VND6774 billion to the state budget, and created 15,1053 local jobs. For these reasons, the research analyzes the impact of industrial park development on people's livelihood. The focus on the central region of Vietnam is necessary, thus, the study brings a significant contribution to the field.

\section{Literature Review}

Industrial park development is of interest not only to researchers, but also to policymakers. The different approaches being implemented include studies conducted to analyze the impact of industrial park development on socio-economic development of countries (e.g., Susur, Hidalgo, \& Chiaroni, 2019; Hyeong et al., 2016; Liang et al., 2018; Milan, Rene, \& Nikola, 2013; Blomstrom \& Ari, 2002; Leonid, Oleksandr, \& Sergiy, 2014; Ramona, 2008; Liang et al., 2017; Nguyen, Nguyen, \& Do, 2017). These studies use primary and secondary data, and input-output resources method to examine the impact of industrial park development on socio-economy. The aim of these studies is consistent when it comes to developing green industrial parks. The recommendations for developing industrial parks were also proposed by the researchers after analyzing data on the actual situation of industrial parks' impacts on the socio-economic situation.

The development of industrial parks affects not only the nation's socio-economic development, but also has an influence on each household living around these industrial parks, agricultural land is acquired and difficulties emerge in developing new livelihood strategies (Dai, Le, \& Nguyen, 2013; Bury, 2004; Bui, Schreinemachers, \& Thomas, 2013). These studies assess livelihood resources as well as the difficulties and advantages of people facing agricultural land acquisition; the livelihood vulnerabilities they encounter are also studied. Data for these studies was collected from the survey of people whose land was acquired in the study areas.

Some research pointed at developing livelihood strategies for people whose land was acquired during industrialization and urbanization, e.g., Tran (2013); Nguyen and Bui (2011); Le (2007); Benayas et al. (2007); Bryceson (1996); Jansen et al. (2006). These studies analyze factors affecting the livelihood of households after land acquisition, and compare the income of households before and after land acquisition. The variables selected to examine the influencing factors have similarities among the studies such as education level, number of employees, gender of household head, area of agricultural land, participation in groups, the social organization of household members, and access to credit.

Besides that, a number of studies directly analyze some factors affecting industrialization of people's livelihood, however, the subjects of these studies are people who acquired agricultural land (Saumik \& Sarma, 2013; Tran, 2013; Nguyen, Duong, \& Nguyen, 2018; Nguyen \& Bui, 2011; Nguyen \& Nguyen, 2020; Ramcharran, 2017). These studies focus on answering the questions: What benefits do households get when their land is acquired to give way to industrialization such as educational activities and livelihood activities? Are there any important difference in the new livelihood of people who have lost land compared to other families? Does the industrial park create work policies for workers? The data this study uses is primary collected from a survey of households that have acquired agricultural land due to industrialization.

Studies also examine the effects of industrial park development on people's livelihood when considering people's vulnerability to habitat changes (Nelson et al., 2010; Adger, Kelly, \& Ninh, 2001; Rohan et al., 2005; Le \& Le, 2020). The vulnerability consists of three main components: expression, sensitivity, and ability to respond to hazards. When studying vulnerability using DFID's sustainable livelihood analysis framework (DFID, 1999), we set adaptive capacity indicators under the influence of external factors. These indicators include the expression or impact and the sensitivity of households living around industrial parks or influenced by industrial parks (Vo \& Nguyen, 2012; Tu et al., 2015; Le et al., 2020).

In summary, these studies have approached different aspects of the influence of industrial park development on people's livelihood. However, the focus of these studies is on households whose land is acquired, not to mention the group of households living around industrial parks affected by industrial parks. 
This research intends to analyze the influence of industrial parks development on people's livelihood using DFID's five livelihood resources approach (DFID, 1999). The object of the study is to target both the households whose agricultural land is recovered and those who do not have land recovered, but live around industrial parks and are affected by industrial parks. The study will analyze both positive and negative impacts of industrial park development on people's livelihood through two steps:

Step 1: research based on survey data to quantify the relationship between the factors affecting the people's income. Many factors affect people's income, however, in this study, the research focuses on analyzing the factors representing industrial development affecting people's livelihood.

Step 2: research and calculate the adaptive capacity and livelihood vulnerability of people subjected to the impact of industrial park development.

\section{Research Methodology}

\subsection{Data Collection Methods}

Using data from the General Statistics Office in 2006 (GSO, 2006), the research team designed a survey questionnaire that included the following information: household characteristics and livelihood resources. The author surveyed households living in industrial parks in five provinces: Thua Thien Hue, Da Nang, Quang Nam, Quang Ngai and Binh Dinh of the Central key economic region. In each area, 150 survey questionnaires were distributed, the total number of questionnaires issued was, thus, 750. 426 questionnaires were collected, out of which 32 questionnaires were eliminated as they did not meet the requirements. There remained 394 valid questionnaires. The number of questionnaires also meets the minimum sample size requirement for the study as per Nguyen (2014).

Primary data was collected from the beginning of May to the end of November 2018 by using the questionnaire through direct interviews with the head of the household. The author uses direct survey method to collect information about households and uses direct survey method in combination with the collecting data related to income, employment of households in the surveyed communes, data on industrial parks for this study.

Besides, the research also uses a focus group discussion method to collect supplementary data for analyzing quantitative data. According to Nguyen (2014), group discussion is often applied when collecting data on emotions and opinions of a group of people related to the research issues. Under the supervision of a research team leader, the subjects shared their opinions, feelings and reactions on relevant issues. The study carried out group discussions with two groups of households: the group of households whose land was acquired and the group of households without land acquisition but had more specific information related to the impact of industrial park development at birth.

The research team selects and invites two groups to discuss, each group includes four representatives from four households; the representative for each household must be knowledgeable on the family's economic conditions as well as about the impact of industrial park development on household livelihood. Individuals participating in group discussions who live in the same residential area and same socio-economic conditions may have different views about the impact of industrial park investment on human livelihood. The researcher selected households living around industrial parks in Binh Dinh province to conduct group discussions. The opinions and shared discussions of the group were recorded fully and saved in the data file.

\subsection{Data Analysis}

\subsubsection{Quantifying the Relationship}

The research uses the OLS model to analyze the relationship between the factors on the income of households living around industrial parks with:

\section{Dependent variable:}

Incomes of households living around industrial parks (Y): household income is the total income that a household earns in a year, the unit of income: million VND/year, as per the research by Nguyen and Bui (2011); Tran (2013); Tran and $\mathrm{Vu}$ (2014); Siegel (2005); Le et al. (2020).

\section{Independent variables:}

Land area lost due to industrial park construction (S_Land): the area of land that households will recover when constructing industrial parks. The unit of calculation is $\mathrm{m} 2$. The author inherits the research by Nguyen (2009); Nguyen, McGrath, and Pamela (2006).

Transportation system after industrial park development (Inf): it is an evaluation variable of households on the transport system after industrial parks are built, according to Saumik and Sarma (2013), better infrastructure system makes people's income decrease. This research finding is contrary to that of Nguyen and Bui (2011).

Number of jobs generated by additional industrial park development (LD): it is the number of jobs calculated for each additional household when industrial parks are built. The unit of calculation is the workers. In the study of Le (2007); Tran (2013) and Le et al. (2020), the increases in the number of jobs contributed to the people's income.

Number of unemployed laborers when building the industrial park (Unempl): the number of employees in each household who was unemployed when the industrial park was built. Calculation unit: workers. According to Nguyen (2009); Le (2007); Le et al. (2020, unemployment is the 
cause of households' poverty. The relationship between unemployed labor and household income is an opposite one.

Besides that, inheriting studies by Nguyen and Bui (2011); Tran (2013); Tran and Vu (2014); Siegel (2005); Huynh and Mai (2011, the study quantifies the relationship among other variables affecting the income of households living around industrial parks such as the age of the head of household (Age), number of workers per household (Empl), cost of living of the household (Cost), habitat (Envi), area of non-agricultural land (S_Nonagri), gender of head of household (Gend), location of residential land of household (VTDD), continued near policy (CS), however, these factors will not focus on the analysis, but will be presented as other factors affecting the income of households living around industrial parks.

\subsubsection{Calculating Adaptive Capacity}

Inheriting the previous work of the authors related to livelihood vulnerability, vulnerability used to determine the characteristics of a person or a group of people and their living conditions that affect their ability to respond, resist and recover from the impact of a hazard (Adger, Kelly, \& Ninh, 2001; Le et al., 2020). The vulnerability consists of three main components: expression, sensitivity, and ability to respond to hazards. Research on vulnerability using a sustainable livelihood analysis framework (DFID, 1999) to set adaptive capacity targets under the influence of external factors, these indicators include the expression or impact and the sensitivity of households living around industrial parks affected by industrial parks (Vo \& Nguyen, 2012; Tu et al., 2015; Saumik \& Sarma, 2013)

In this research, vulnerability is defined as the opposite of adaptive capacity. When adaptive capacity is high, households will be less vulnerable and vice versa. In other words, the connection between vulnerability and adaptive capacity is expressed by the following formula:

Vulnerability (VI) = 1- Adaptive capacity

Calculation of the vulnerability index (VI)

The study will focus on calculating the adaptive capacity index (ACI). Because these indicators are evaluated and measured on different scales, before calculating the ACI index, the criteria will be standardized and then calculated by the average principle according to the formula of human development index (HDI) of Anand and Sen (1994); the formula is described as follows:

$$
\mathrm{SI}_{\mathrm{i}}=\left(\mathrm{In}_{\mathrm{i}}-\mathrm{In}_{\text {min }}\right) /\left(\mathrm{In}_{\text {max }}-\mathrm{In}_{\text {min }}\right)
$$

Where:

$\mathrm{SI}_{\mathrm{i}}$ : is the normalized indicators according to criterion $\mathrm{i}$
$\mathrm{In}_{\mathrm{i}}$ : is the average index of criterion $\mathrm{i}$

$\mathrm{In}_{\max }$ và $\mathrm{In}_{\min }$ : are the largest and smallest indexes of criterion i

After each criterion has been normalized, all criteria of a livelihood resource will be averaged to formulate the standards of each livelihood resource (human, social, physical, financial and natural). The formula for calculating the index of resources is as follows:

$$
\mathrm{IC}_{\mathrm{j}}=\sum_{1}^{\mathrm{i}} \mathrm{SI}_{\mathrm{i}} / \mathrm{i}
$$

Where:

$\mathrm{IC}_{\mathrm{j}}$ : is an indicator of each livelihood resource.

SI: is Normalized value of each criterion

$\mathrm{i}$ : is the total number of criteria of a livelihood resource

After calculating the index of each livelihood resource, the adaptive capacity index (ACI) is calculated as follows: The ACI will be weighted average according to the importance of each criterion contributing to adaptive capacity. These weighted values are inherited from the study of Tu et al. (2015), the adaptive capacity index is calculated by the following formula:

$$
\mathrm{ACI}=\sum_{1}^{5} \mathrm{~W}_{\mathrm{j}} \times \mathrm{IC}_{\mathrm{j}} / \sum \mathrm{W}_{\mathrm{j}}
$$

Where:

$\mathrm{W}_{\mathrm{j}}$ : is the weight of $\mathrm{jth}$ livelihood resources

$\mathrm{IC}_{\mathrm{i}}$ : is the index of each jth livelihood resources

Inheriting previous research, the weighting of livelihood investment resources namely for financial resources and human resources have a weight of 10 , social and natural resources are 9 and physical resources are 8 (Tu et al., 2015).

\section{Research Findings}

\subsection{Analyze Factors on the Income of Households}

The study carried out checking the conformity of the regression model. With the coefficient $\mathrm{R}$ Square $=0.836$, the coefficient Sig $=0.000$, and test $\mathrm{F}=162.134$, the research model is appropriate (see Table 1).

The author's calculation results show that, with land area acquired due to industrial park construction (S_Land), the coefficient of the variable of the land area lost due to industrial park construction is 0.031 . It means that when people are withdrawn to build industrial parks, their income increases. The people who have money for compensation from losing land due to the construction of industrial parks have changed to a new livelihood: from farming to trading goods, providing services or building motels for workers. The research findings support Nguyen (2009); Nguyen et al. (2006). 
Table 1: Regression results

\begin{tabular}{|l|c|c|c|}
\hline Variables & $\begin{array}{c}\text { Standardized } \\
\text { Coefficients } \\
\text { (Beta) }\end{array}$ & $\mathbf{T}$ & Sig. \\
\hline (Constant) & .048 & .261 & .794 \\
\hline Age & .052 & 2.282 & .034 \\
\hline Empl & .373 & 12.136 & .000 \\
\hline S_Land & .053 & 2.099 & .037 \\
\hline Cost & .044 & 2.069 & .039 \\
\hline Inf & -.007 & -.333 & .740 \\
\hline Envi & .600 & 20.042 & .000 \\
\hline S_Nonagri & .068 & 2.991 & .003 \\
\hline LD & -.077 & -3.016 & .003 \\
\hline Unempl & .157 & 4.302 & .000 \\
\hline CS & -.027 & -1.289 & .198 \\
\hline Gend & .074 & 3.227 & .001 \\
\hline VTDD & & & \\
\hline
\end{tabular}

Transportation system after developing the industrial park (Inf): the research findings show that when the transportation system is more convenient, the people's income increases. With the coefficient of traffic system variable after the industrial park is 4,627; the author's research findings are not similar to those of Saumik and Sarma (2013). When the industrial park is built, the transport system will be upgraded to meet the transportation needs of enterprises operating in industrial parks, this is absolutely favorable to households doing business and trading around industrial parks. Therefore, the more convenient the transportation system, the more people's income increases.

The number of jobs increased when industrial parks were built (LD): the number of extra jobs created when constructing industrial parks contributes to increasing incomes for people living around the industrial parks. The coefficient of this research variable is 5,796; the research findings also support previous studies by Le (2007); Tran (2013); Tran and Vu (2014); Le et al. (2020).

The number of unemployed laborers when the industrial parks are built (Unempl): The coefficient of this variable is $(-7,729)$, which indicates the inverse relationship between the number of unemployed laborers and the income of households. It is undeniable that, when constructing industrial parks, there are households who will be unemployed because they have not caught up with the opportunities created by the construction of industrial parks. As a result, the number of unemployed workers remains static, the income of households decreases and, at the same time, the relationship between the unemployed labor in the construction of the industrial park and the income of the household is in an opposite relationship.
The research findings also support previous studies by Nguyen (2009); Le (2007); Le et al. (2020).

\subsection{Calculating Adaptive Capacity of the People}

As shown in formula (1), instead of calculating the vulnerability index, the study will focus on the adaptive capacity index. Research findings of the adaptive capacity indicators of households are shown on Table 2 and 3. Calculation results from criteria, adaptive capacity index after calculating the weight of physical resources is 0.434 ; Physical Vulnerability index returns the value of 0.566 .

When considering human resources, the specific criteria for this resource are the number of household members, age of household head, number of employees in the household, education level, number of jobs, there are more when building industrial parks, the number of direct labor in industrial parks, and the number of unemployed workers. The adaptive capacity index is calculated after taking into account the weight of human resources - 0.39 - and the injury index of this resource is 0.61 .

Using data from focus group discussions, the opinions of households living around the industrial zone on the impact of industrial park development on human resources are as follows:

Question: How do you assess the impact of industrial park development on family life?

*) Group of households that did not lose land:

Q1: After having industrial parks,

My family turned to selling groceries serving workers who are working at factories in industrial parks, the life is less strenuous and difficult than before. As my husband and I don't know how to use computers, without vocational training, so cannot apply for work in industrial parks. If possible, we just could work as a sewing worker, we would open a shop at home. My son and daughter-in-law both got a job in the industrial park, and their incomes were stable.

Q2: When having a factory in an industrial park, my son applied to be a technical worker in the factory. When I got an industrial park my son got a job

Q3: My family did not change after developing the industrial park because both my husband and I are civil servants my children are going to school.

Q4: My family has also no changed

*) Group of households whose land acquired

Q1: After developing the industrial park, my agricultural land area is no longer available, I would like to work as a garment factory worker, my husband stays at home and takes care of the house and family. My daughter works for a enterprise in an industrial park. 
Table 2: Adaptive capacity indicators of physical resources

\begin{tabular}{|l|c|c|c|c|c|}
\hline Physical Resources & $\begin{array}{c}\text { Transportation } \\
\text { after } \\
\text { industrial park } \\
\text { development }\end{array}$ & $\begin{array}{c}\text { Clean } \\
\text { water after } \\
\text { industrial } \\
\text { park } \\
\text { development }\end{array}$ & $\begin{array}{c}\text { \% assessment } \\
\text { of household } \\
\text { about access } \\
\text { to education } \\
\text { is better when } \\
\text { industrial park } \\
\text { development }\end{array}$ & $\begin{array}{c}\text { \% assessment } \\
\text { of household } \\
\text { about the quality } \\
\text { of the living } \\
\text { environment } \\
\text { industrial park } \\
\text { development }\end{array}$ & $\begin{array}{c}\text { \% assessment of } \\
\text { household about } \\
\text { medical quality } \\
\text { is better when } \\
\text { industrial park } \\
\text { development }\end{array}$ \\
\hline Real value & 2.72 & 2.44 & 68 & 46 & 78.8 \\
\hline Min & 1 & 1 & 0 & 0 & 0 \\
\hline Max & 5 & 5 & 100 & 100 & 100 \\
\hline $\begin{array}{l}\text { Adaptive index is } \\
\text { normalized (Sli) }\end{array}$ & 0.36 & 0.68 & 0.46 & 0.788 \\
\hline IC index of physical resources & & 0.5436 & & \\
\hline Adaptive capacity index $(\mathrm{ACl})$ & & 0.434 & & \\
\hline \multicolumn{2}{|l|}{ Physical vulnerability index $(\mathrm{VI})$} & 0.566 & & \\
\hline
\end{tabular}

Table 3: Adaptive capacity indicators of human resources

\begin{tabular}{|l|c|c|c|c|c|c|c|}
\hline Human resources & $\begin{array}{c}\text { Number of } \\
\text { household } \\
\text { members }\end{array}$ & $\begin{array}{c}\text { Age of } \\
\text { household } \\
\text { head }\end{array}$ & $\begin{array}{c}\text { Number of } \\
\text { workers } \\
\text { in the } \\
\text { household }\end{array}$ & $\begin{array}{c}\text { The average } \\
\text { educational } \\
\text { level of the } \\
\text { family }\end{array}$ & $\begin{array}{c}\text { The } \\
\text { number } \\
\text { of jobs } \\
\text { increased }\end{array}$ & $\begin{array}{c}\text { Number } \\
\text { of direct } \\
\text { workers in } \\
\text { industrial } \\
\text { parks }\end{array}$ & $\begin{array}{c}\text { Number of } \\
\text { unemployed } \\
\text { workers }\end{array}$ \\
\hline Real value & 4.23 & 52.38 & 2.7 & 9.08 & 1.28 & 1.08 & 0.78 \\
\hline Min & 1 & 28 & 1 & 0 & 0 & 0 & 0 \\
\hline Max & 10 & 86 & 6 & 13 & 4 & 4 & 2 \\
\hline $\begin{array}{l}\text { Adaptive index is } \\
\text { normalized (Sli) }\end{array}$ & 0.358 & 0.42 & 0.34 & 0.698 & 0.32 & 0.27 & 0.39 \\
\hline IC index of human resources & & & \\
\hline
\end{tabular}

Before the land was acquired, my husband and I were farmers, raised pigs and chickens to raise our children to go to school, have no more fields, so I work as a worker, my husband at home but unfortunately for her daughter out of school and should also be less strenuous.

Q2: My son did not study well, dropped out of school in 7th grade, so now he cannot apply to work as a factory worker, he stays at the chicken house, I go to work in the city.

Q3: After the acquisition of agricultural land, my family used that money to build houses to support workers for rent, a part to open a construction material store, hire two additional workers to help, and life was okay more determined than before.

Q4: My house opened a grocery store and sold breakfast to the workers, both of us worked together because I couldn't make it alone. I find it hard but better when I'm working in the field.

Comments by the authors: industrial park development brings both benefits as well as difficulties for the households living around these parks: it has just created new jobs for the people, but for those households who do not meet the professional requirements, their skills have a negative impact such as unemployment (see Table 4).

Criteria of natural resources include: criteria for the quality of agricultural land, criteria of agricultural land area, non-agricultural land area, recovered land area, and residential land position of the family

People's comments about changes in human resources when industrial parks are developed: 
Question: How do you assess the impact of industrial park development on the living environment and location of residential land of the family?

*) Group of households whose land is acquired

Q1: I find the air is more polluted than before, the population is more crowded, so the waste and domestic wastewater are very uncomfortable, in many areas, sewage spills out into the streets, polluting the surrounding people

Q2: I see no change

Q3: I see an industrial park, transportation system is better than in 2012. You came here, then move from Hanoi to our place, it takes about 3 to 4 hours by bus, now it's easier to go, it only takes about an hour to come. Many families have turned to business because of new roads the houses are turning from alleys into big roads. I see an industrial park has also changed a lot

Q4: I feel the same as before

*) Group households without land acquisition:

There is no change compared to before
Reviews of the research team: the development of industrial parks affects the land area of households in the land acquisition group, their cultivated land area decreases, some areas are affected by wastewater and air, so the quality of their agricultural land is also partially affected, but due to many years of cultivation without intensive farming and soil care, it will also greatly affect the quality of farming. Therefore, the influence of industrial park development is only one factor causing an impact on the quality of arable land.

The result of calculating the adaptive capacity index of natural resources is 0.324 (see Table 5).

Calculated results from the survey data show the adaptive capacity index of social resources is 0.395 after taking into account the weight of resources; the vulnerability index of people on social resources is 0.605 (see Table 6).

Adaptive capacity index of financial resources after considering the weight of resources is about 0.34. After calculating the adaptive capacity index (ACI) of each livelihood resource, the author calculates the general adaptive capacity index showing the adaptive capacity of the people under the influence of the development of the area.

Table 4: Adaptive capacity indicators of natural resources

\begin{tabular}{|l|c|c|c|c|c|}
\hline Natural resources & $\begin{array}{c}\text { Quality of } \\
\text { agricultural } \\
\text { land }\end{array}$ & $\begin{array}{c}\text { Area of } \\
\text { agricultural } \\
\text { land }\end{array}$ & $\begin{array}{c}\text { Area of non- } \\
\text { agricultural } \\
\text { land }\end{array}$ & $\begin{array}{c}\text { Land area is } \\
\text { lost }\end{array}$ & Land location \\
\hline Real value & 2.35 & 1444.31 & 833.378 & 793.782 & 40.9 \\
\hline Min & 1 & 0 & 50 & 0 & 0 \\
\hline Max & 5 & 4351.2 & 3200 & 2500 & 100 \\
\hline Adaptive index is normalized (Sli) & 0.470 & 0.33 & 0.25 & 0.32 & 0.409 \\
\hline IC index of natural resources & 0.36 & & & \\
\hline Adaptive capacity index (ACl) & 0.324 & & & \\
\hline Natural Vulnerability index (VI) & 0.676 & & & \\
\hline
\end{tabular}

Table 5: Adaptive capacity indicators of social resources

\begin{tabular}{|l|c|c|c|}
\hline Social resources & $\begin{array}{c}\% \text { households } \\
\text { participated in } \\
\text { training courses }\end{array}$ & $\begin{array}{c}\% \text { households } \\
\text { with members } \\
\text { participating in } \\
\text { social organizations }\end{array}$ & $\begin{array}{c}\text { \% households receive } \\
\text { support from the } \\
\text { government and local } \\
\text { authorities }\end{array}$ \\
\hline Real value & 50.3 & 53 & 29 \\
\hline Min & 0 & 0 & 0 \\
\hline Max & 100 & 100 & 100 \\
\hline Adaptive index is normalized (Sli) & 0.503 & 0.525 & 0.29 \\
\hline IC index of financial resources & & 0.439 \\
\hline Adaptive capacity index (ACl) & 0.395 \\
\hline Social vulnerability index (VI) & 0.605 \\
\hline
\end{tabular}


Table 6: Adaptive capacity indicators of financial resources

\begin{tabular}{|l|c|c|c|c|c|}
\hline Financial resource & $\begin{array}{c}\text { Non-agricultural } \\
\text { investment }\end{array}$ & $\begin{array}{c}\text { Living } \\
\text { expenses }\end{array}$ & $\begin{array}{c}\text { The amount of } \\
\text { compensation }\end{array}$ & $\begin{array}{c}\text { Household } \\
\text { income }\end{array}$ & $\begin{array}{c}\text { \% household income } \\
\text { increases after industrial } \\
\text { park development }\end{array}$ \\
\hline Real value & 108.24 & 66.58 & 88.91 & 127.67 & 35.1 \\
\hline Min & 0 & 12 & 0 & 42 & 0 \\
\hline Max & 480 & 116 & 250 & 386 & 100 \\
\hline $\begin{array}{l}\text { Adaptive index is } \\
\text { normalized (Sli) }\end{array}$ & 0.24 & 0.525 & 0.356 & 0.25 & 0.351 \\
\hline IC index of financial resources & & 0.34 & & \\
\hline Adaptive capacity index (ACl) & 0.34 & & \\
\hline \multicolumn{2}{l|}{ Financial vulnerability index (VI) } & 0.66 & & \\
\hline
\end{tabular}

From formula (3) and the results of the calculation of the adaptive capacity of the resources, the adaptive capacity of the people after the impact of industrial park development have considered the weight of 0.376 . From there, the author calculated the livelihood vulnerability of the people at 0.624 .

\section{Conclusions}

From the results of the analysis and calculation above, it shows that the adaptive capacity of households, when the living environment changes, is relatively low or, in other words, high vulnerability. Specifically, for each household's investment resources, human and financial resources are the two most important resources, but the adaptive capacity index is still quite low, at 0.42 and 0.2064 , respectively. In terms of human resources, the low adaptive capacity index is due to the low level of household members surveyed - on average, it only reaches grade 9 and the number of household members is high. However, the number of members of working age is quite low, which affects the adaptive capacity of households. For financial resources, the adaptive capacity index is low because the total income among households is quite large. The difference between the compensation amounts for land loss to households is relatively high and, possibly, the access to bank loans by households is uneven. Similarly, with natural resources, physical resources and social resources, the adaptive capacity index is quite low as the vulnerability of these resources is quite high.

In summary, the vulnerability index of households living around industrial parks, influenced by the development of industrial parks, is quite high, about 0.6 per 1. In particular, financial resources and natural resources are the lowest and most influential resources to increase vulnerability. However, according to the research findings, the three resources are human resources (the most important), physical resources and social resources.
They are important in the process of adapting or reducing household vulnerability as three resources will contribute to the strengthening of the livelihood resources in the long run and also resources that are assessed to change easily with outside intervention.

Due to the limited livelihood resources of the household, households are made vulnerable when the environment changes, namely, when industrial parks are built and developed. Regarding social resources, due to the lack of information, households will face difficulties in the early phase when the new environment changes and push for adaptation. Regarding human resources, due to the low level of education and training, the ability to obtain and get suitable jobs is limited. Regarding financial resources, as most households are purely agricultural before building industrial parks, their income depends largely on agriculture and traditional income-generating methods, therefore when industrial parks are built, households do not have sufficient financial resources for a new livelihood strategy. Besides, the income differences among the surveyed households are quite high. Regarding natural resources, when industrial parks are built, the agricultural land area of households is narrowed due to land acquisition; therefore, the livelihood of households is seriously affected; besides, after the industrial park is built, the position regarding the residential land of most households is not advantageous for production and business activities. The research findings show that investment resources for households' livelihood affect the adaptive capacity to enhance this livelihood. Firstly, attention should be paid to develop human resources, financial resources and social resources. The reasons for the improvement of these resources are that these are important resources in the livelihood strategies of households and also have an influence on other resources. The research findings also support Nelson et al. (2010); Tu et al. (2015). 
Thus, industrial park development has both positive and negative impacts on the livelihood of households living around these industrial parks, directly affecting financial resources and human resources. To enhance the livelihood of people living around the industrial parks, households need appropriate strategies, besides that, there should be policies to support local authorities to meet the quality requirements of employer resources.

\section{References}

Adger. W. N., Kelly, P. M., \& Ninh, N. H. (2001). Environment, Society and precipitous change, in living with environmental change: social vulnerability, adaptation and resilience in Viet Nam. London, UK: Routlege.

Anand, S., \& Sen, A. K. (1994). Human development index: Methodology and measurement. The Human Development Report Office of the United Nations Development Programme. Available at: http://hdr.undp.org/sites/default/files/oc12.pdf

Benayas. J. M. R., Ana, M., Jose M. N., \& Jennifer J. S. (2007). Abandonment of agricultural land: An overview of drivers and consequences. CAB Reviews: Perspectives in Agriculture, Veterinary Science, Nutrition and Natural Resources, 2(57), 1-14. doi: 10.1079/PAVSNNR20072057

Blomstrom, M., \& Ari, K. (2002). Multinational Corporations and Spillovers. Journal of Economic Surveys, 12(3), 247-277. https://doi.org/10.1111/1467-6419.00056

Bui, T. M. H., Schreinemachers, P., \& Thomas, B. (2013). Hydropower development in Viet Nam: Involuntary resettlement and factors enabling rehabilitation. Land Use Policy. 31, 536-544. https://doi.org/10.1016/j.landusepol.2012.08.015

Bury, J. (2004). Livelihood in transition: Transnational gold mining operation and local change in Cajamarca, Pery. The Geographical Journal, 170, 78-91. https://doi.org/10.1111/ j.0016-7398.2004.05042.x

Bryceson, D. F. (1996). Deagrarianization and rural employment in sub-Saharan Africa: A sectoral perspective. World Development, 24(1), 97-111. https://doi.org/10.1016/0305-750X(95)00119-W

Dai, D., Le, N., \& Nguyen, T. D. (2013). Difficulties in transition among livelihood under agricultural land conversion for industrialization: Perspective of human development, Mediterranean Journal of Social Sciences, 4(10), 259-267.

DFID. (1999). Sustainable livelihood guidance sheets. Upper Saddle River, NJ: Prentice Hall International

GSO. (2006). Vietnam Household Living Standards Survey 2006. Hanoi, Vietnam: General Statistics Office. [Vietnamese]

Huynh, T. D. X., \& Mai, V. N. (2011). Analysis of factors affecting the income of poultry farmers in the Mekong Delta. Scientific Journals, 17(b), 87-96. [Vietnamese]

Hyeong, W. K., Liang, D., Angelo, E. S. C., Minoru, F., Tsuyoshi, F., \& Hung, S. P. (2018). Co-benefit potential of industrial and urban symbiosis using waste heat from industrial park in Ulsan, Korea. Resources Conservation Recycling, 135, 225-234. https://doi.org/10.1016/j.resconrec.2017.09.027

Jansen, H. G. P., John, P., Amy, D., Willem, W., \& Rob, S. (2006). Policies for sustainable development in the hillside areas of Honduras: A quantitative livelihoods approach. Agricultural Economics, 34, 141-153. https://doi.org/10.1111/j.15740864.2006.00114.x

Liang, D., Tsuyoshi, F., Ming, D., \& Yong, G. (2015). Towards preventative eco-industrial development: an industrial and urban symbiosis case in one typical industrial city in China. Journal of Clean Production, 114, 387-400. https://doi. org/10.1016/j.jclepro.2015.05.015

Liang, D., Hanwei, L., Liguo Z., Zhaowen L., Zhiqiu, G., \& Mingming, H. (2017). Highlighting regional eco-industrial development: Life cycle benefits of an urban industrial symbiosis and implications in China. Ecological Modelling, 361, 164-176. https://doi.org/10.1016/j.ecolmodel.2017.07.032

Le, D. P. (2007). Income, life, work of people whose land is acquired to build industrial parks, urban areas of socio-economic infrastructure, projects serving national interests. Hanoi, Vietnam: National Political Publishing House. [Vietnamese]

Leonid, M., Oleksandr, K., \& Sergiy, P. (2014). The impact of foreign direct investment on economic growth: Case of post communism transition economies. Problems and Perspectives in Management, 12(1), 17-24.

Le, T., Pham, V., Cu, T., Pham, M., \& Dao, Q. (2020). The effect of industrial park development on people's lives. Management Science Letters, 10(7), 1487-1496. doi: 10.5267/j. msl.2019.12.018

Le, L. H., \& Le, T. N. (2020). Determinants of Income Diversification among Rural Households in the Mekong River Delta: The Economic Transition Period. Journal of Asian Finance, Economics and Business, 7(5), 291-304. doi:10.13106/jafeb.2020.vol7.no5.291

Milan, D., Rene, W., \& Nikola, M. K. (2013). The effectiveness of industrial zones support in the Czech Republic. Journal of Ekonomika and Management, 16(4), 104-117.

Nelson, R., Kokic, P., Crimp, S., Martin, P., Meinke, H., Howden, S. M., Voil, P. D., \& Nidumolu, U. (2010). The vulnerability of Australian rural communities to climate variability and change: Part II- integrating impacts with adaptive capacity. Environmental Science and Policy, 13(1), 18-27. https://doi. org/10.1016/j.envsci.2009.09.007

Rohan, N., Philip, K., Elliston, L., \& King, J. A. (2005). Structural adjustment: a vulnerability index for Australian broadacre Agriculture, Australian Commodities, 12(1), 171-179.

Nguyen, T. D., Nguyen, A. T., \& Do, P. T. T. (2017). The Role of Investment Attraction in Vietnamese Industrial Parks and Economic Zones in the Process of International Economic Integration. Journal of Asian finance, Economics and Business, 4(3), 27-34, doi:10.13106/jafeb.2017.vol4.no3.27 
Nguyen, V. T. (2014). Curriculum of research practice in economics and business administration. Hanoi, Vietnam: National Economics University Publishing House. [Vietnamese]

Nguyen, Q. N., \& Bui, V. T. (2011). Factors affecting the income of ethnic minorities in the Mekong Delta. Scientific Journals, 18(a), 240-245. [Vietnamese]

Nguyen, M. T., Duong, N. T., \& Nguyen, T. N. (2018). Factors affecting households' income after land acquisition for industrial park construction in Vinh Long province. Scientific Journals, 54(4b), 80-90. DOI:10.22144/ctu.jvn.2018.073 [Vietnamese]

Nguyen, V. C., McGrath, T., \& Pamela, W. (2006). Agricultural land distribution in Vietnam: Emerging issues and policy implications. MPRA Paper No. 25587. https://mpra.ub.unimuenchen.de/25587/1/MPRA_paper_25587

Nguyen, V. S. (2009). Industrialisation and urbanisation in Vietnam: How appropriation of agricultural land use rights transformed farmers Livelihoods in a Per-Urban Hanoi Village?. EADN Working Paper. Retrieved January 10, 2020 from: https:// landportal.org/library/resources/industrialization-andurbanization-vietnam-how-appropriation-agricultural-land-use

Ramona, F. P. (2008). Eco-industrial parks - an opportunity for the developing countries to achieve sustainable development. Zagreb International Review of Economics and Business, 11(special issue), 21-33. https://hrcak.srce.hr/78666

Ramcharran, H. (2017). The impact of workers' remittances on household consumption in India: Testing for consumption Augmentation and stability. Journal of Asian Finance, Economics and Business, 4(4), 51-60. http://dx.doi. org/10.13106/jafeb.2017.vol4.no4.51

Saumik, P., \& Sarma, V. (2013). The livelihood effects of industrialization on displaced households: Evidence from Falta special economic zone, West Bengal. Centre for European Economic Research Discussion, 13(83), 1-32. http://dx.doi. org/10.2139/ssrn.2343143

Siegel, P. (2005). Using an asset-based approach to identify drivers of sustainable rural growth and poverty reduction in Central America: A conceptual framework. World Bank Policy Research Working Paper 3475. Available at: https://elibrary. worldbank.org/doi/abs/10.1596/1813-9450-3475

Susur, E., Hidalgo, A., \& Chiaroni, D. (2019). A strategic niche management perspective on transitions to eco-industrial park development: A systematic review of case studies. Resources Conservation Recycling, 140, 338-359. https://doi. org/10.1016/j.resconrec.2018.06.002

Nguyen, T. A. N., \& Nguyen, K. M. (2020). Role of Financial Literacy and Peer Effect in Promotion of Financial Market Participation: Empirical Evidence in Vietnam. Journal of Asian Finance, Economics and Business, 7(6), 73-84. doi:10.13106/ jafeb.2020.vol7.no6.073

Tran, Q. T. (2013). Livelihood strategies for coping land loss among households in Vietnam's sub-urban areas. Asian Social Science, 9(15), 33-46. doi:10.5539/ass.v9n15p33

Tran, Q. T., \& Vu, V. H. (2014). The impact of land loss on household income: The case of Hanoi's sub-urban areas, Viet Nam, International Journal of Business and Society, 15(2), 339-358.

Vo, H. T., \& Nguyen, T. T. (2012). Vulnerability of farmers affected by floods in An Giang province and response solutions. Scientific Journals, 22(b), 294-303. [Vietnamese]

Tu, V. H., Mitsuyasu, Y., Nguyen, T. T., \& Huynh, V. K. (2015). Adaptive capacity assessment of rural out migrants: A case study of An Giang province, Viet Nam. Journal of the Faculty of Agriculture Kuyshu University, 60, 265-271. 